\title{
Terapötik Hipotermi Uygulanan Hipoksik İskemik Ensefalopatili Yenidoğanların Kardiyak Bulgularının Değerlendirilmesi
}

\section{Evaluation of Cardiac Manifestations in Neonates With Hypoxic İschemic Encephalopathy Received Therapeutic Hypothermia}

Emine AZAK', Burak CERAN² ${ }^{2}$, Denizhan BAĞRUL ${ }^{1}$, Betül SIYAH BILGIN², Hayriye Gözde KANMAZ KUTMAN², Fuat Emre CANPOLAT2,3, İbrahim Illker ÇETIN ${ }^{1,4}$

${ }^{1}$ Ankara Şehir Hastanesi, Çocuk Hastanesi, Çocuk Kardiyoloji Kliniği, Ankara, Türkiye

${ }^{2}$ Ankara Şehir Hastanesi, Çocuk Hastanesi, Çocuk Yenidoğan Yoğun Bakım Kliniği, Ankara, Türkiye

${ }^{3}$ Sağlık Bilimleri Üniversitesi, Tıp Fakültesi, Çocuk Sağlığı ve Hastalıkları Anabilim Dalı, Yenidoğan Bilim Dalı, Ankara, Türkiye

${ }^{4}$ Yıldırım Beyazıt Üniversitesi, Tıp Fakültesi, Çocuk Sağlığı ve Hastalıkları Anabilim Dalı, Çocuk Kardiyoloji Bilim Dalı, Ankara, Türkiye

\section{ÖZ}

Amaç: Terapötik hipotermi tedavisi alan hipoksik iskemik ensefalopatili (HiE) yenidoğanların kardiyak bulgularının; biyobelirteçler, EKG ve ekokardiyografi ile değerlendirilmesi ve bu belirteçlerin hipoksik myokard hasarı şiddetinin belirlenmesindeki etkisinin araştırıması amaçlanmıştır.

Gereç ve Yöntemler: Evre II ve III HİE tanısı alan ve terapötik hipotermi uygulanmış 50 yenidoğan bebeğin verileri retrospektif olarak incelendi. Demografik özellikler, sistemik ve kardiyak muayene bulguları, serum CK-MB, troponin-I, EKG ve ekokardiyografi raporları kaydedildi. Evre II ve Evre III HiE'li hastaların bulguları karşılaștırıldı.

Bulgular: Elli olgunun 11'inde (\%22) miyokardiyal disfonksiyon saptandı. EKG kayıtlarında tüm olgular normal sinüs ritmine sahipti. EKG'de patolojik bulgu evre Il'de 2 (\%8.3) olguda, evre III'de ise 5 (\%19.8) olguda mevcuttu. Serum CKMB ve troponin-I olguların 30'unda (\%60) yüksek izlendi. Tüm olguların 5'inde (\%10) orta derecede triküspit yetersizliği, 1'inde (\%2) şiddetli triküspit yetersizliği, 4'ünde (\%8) sağ ventrikül hipokinezisi, 6'sında (\%12) sol ventrikül hipokinezi ve 1'inde (\%2) biventriküler hipokinezi mevcuttu. Evre III HíE'li olgularda enzim düzeylerinin daha yüksek, EKG ve EKO anormalliklerinin daha yaygın olduğu görüldü $(p<0.05)$.

Sonuç: Hipoksik iskemik ensefalopatili yenidoğanlarda kardiyak etkilenme prognoz açısından son derece önemlidir. Olgularda tedavinin daha iyi yönetilmesi için kardiyak değerlendirme ve yakın takip çok önemlidir. Kardiyak biyobelirteçler, EKG ve EKO perinatal asfikside miyokardiyal hasarın ciddiyetinin erken tanı ve değerlendirilmesinde faydalıdır.

Anahtar Sözcükler: Kardiyovasküler insitabilite, Miyokardiyal hasar, Perinatal asfiksi

\section{ABSTRACT}

Objective: The aim of this study is to evaluate the severity of cardiac complications of hypoxic ischemic encephalopathy $(\mathrm{HIE})$ according to the degree of hypoxia and to evaluate the efficacy of cardiac biomarkers, electrocardiography (ECG) and echocardiography $(\mathrm{ECHO})$ for myocardial injury.

(10)

AZAKE

CERAN B

BAĞRUL D

SIYAH BILGIN B

KANMAZ KUTMAN HG

CANPOLAT FE

CETIN iI
$0000-0002-7841-1331$ 0000-0001-5914-5325 0000-0003-0375-1726 0000-0003-3807-4809 :0000-0002-3177-9411 $0000-0001-9307-3003$ 0000-0001-9480-8278
Çıkar Çatıșması / Conflict of Interest: Tüm yazarlar adına, ilgili yazar çıkar çatıșması olmadığını belirtir

Etik Kurul Onayı / Ethics Committee Approval: Bu çalıșma Helsinki Deklarasyonu Illkelerine uygun olarak yapılmıştır. Çalışma için, Ankara Şehir Hastanesi etik kurul onayı alınarak gerçekleștirildi( 07.04.2021- E2-21-375).

Yazarların katkısı / Contribution of the Authors: AZAK E: Araştırma ve/veya makalenin hipotezini veya fikrini oluşturan, Sonuçlara ulaşmak için planlama/metodoloji belirleme, Araşııma/çalışmanın sorumluluğunu üstlenmek, ilerlemenin seyrini denetlemek, Hasta takibinde sorumluluk almak, ilgill biyolojik malzemelerin toplanması, veri yönetimi ve raporlama, deneylerin yürütülmesi, Sonuçların mantıksal olarak Yorumlanması ve sonuçlandırıması, Çalısma için gerekli literatür taramasında sorumluluk almak, Çalışmanın bütününün veya önemli bölümlerinin yazımında sorumluluk almak, Yazım ve dilbilgisi dıșında bilimsel olarak gönderilmeden önce makaleyi gözden geçirme. CERAN B: Sonuçlara ulașmak için planlama/metodoloji belirleme, Araștırma/çalısmanın sorumluluğunu üstlenmek, ilerlemenin seyrini denetlemek, Hasta takibinde sorumluluk almak, ilgili biyolojik malzemelerin toplanmasi, veri yönetimi ve raporlama, den e raporlama deneylerin yürr̈tülmesi, Sonucları mantısal olarak Yorumlanması ve sonuçlandirıması, Calısma icin gerekli literatür taramasında sorumluluk almak. SiYAH BiLGiN B: Hasta takibinde sorumluluk almak, ilgili biyolojik malzemelerin toplanması, veri yönetimi ve raporlama, deneylerin yürütülmesi, Çalışmanın bütününün veya önemli bölümlerinin yazımında sorumluluk almak. KANMAZ KUTMAN HG: Sonuçlara ulașmak için planlama/ metodoloji belirleme, Araștıma/ç̧alıșmanın sorumluluğunu üstlenmek, ilerlemenin seyrini denetlemek, Sonuçların mantıksal olarak Yorumlanması ve sonuçlandırıması, Çalıșma için gerekli literatür taramasında sorumluluk almak, Çalıșmanın bütününün veya önemli bölümlerinin yazımında sorumluluk almak, Yazım ve dilbilgisi dıșında bilimsel olarak gönderilmeden önce makaleyi gözden geçirme. CANPOLAT FE: Araștırma ve/veya makalenin hipotezin veya fikrini olușturan, Araștırma/çalıșmanın sorumluluğunu üstlenmek, ilerlemenin seyrini denetlemek, Sonuçların mantıksal olarak Yorumlanması ve sonuçlandırıması, Calıșmanın bütününün veya önemli bölümlerinin yazımında sorumluluk almak. ÇETiN ii: Araștırma/çalıșmanın sorumluluğunu üstlenmek, ilerlemenin seyrini denetlemek, Yazım ve dilbilgisi dışında bilimsel olarak gönderilmeden önce makaleyi gözden geçirme.

Atıf yazım şekli / How to cite : Azak E, Ceran B, Bağrul D, Siyah Bilgin B, Kanmaz Kutman HG, Canpolat FE ve ark. Terapötik Hipotermi Uygulanan Hipoksik İskemik Ensefalopatili Yenidoğanların Kardiyak Bulgularının Değerlendirilmesi. Türkiye Çocuk Hast Derg 2021;15:400-407.
Yazışma Adresi / Correspondence Address:

Emine AZAK

Ankara Sehir Hastanesi, Cocuk Hastanesi, Çocuk Kardiyoloji Kliniği, Ankara, Türkiye

E-posta: azakemi@gmail.com
Geliş tarihi/ Received : 01.07.2021 Kabul tarihi / Accepted : 17.08.2021 Elektronik yayın tarihi : 10.09.2021 Online published

DOI: 10.12956/tchd.958211 
Material and Methods: Fifty term babies with HIE without any additional disease were selected. Myocardial dysfunction was evaluated using clinical examination, serum CK-MB, troponin-I and ECG and ECHO.

Results: According to Sarnat and Sarnat classificiation, 24 neonates were diagnosed stage II and 26 neonates were diagnosed stage III HIE. Among these 50 cases, 11 (22\%) had evidence of myocardiac dysfunction. All the cases had normal sinus rhythm. ECG changes (ST depression, T wave inversion, pathological Q wave as signs of ischemia) were present in 2 (8.3\%) cases in the stage II, and 5 (19.8\%) cases in the stage HIE group. ECG showed. Serum levels of troponin-I and CK-MB were increased in 30 (60\%) patients. Moderate tricuspid regurgitation was present in 5 (10\%), severe tricuspid regurgitation in 1 (2\%), right ventricular hypokinesia in 4 (8\%), left ventricular hypokinesia in 6 (12\%) and biventricular hypokinesia in 1 (2\%) neonate among all the cases. Enzyme levels were higher, ECG and ECHO abnormalities were more common in the neonates with stage III HIE $(p<0.05)$.

Conclusion: Cardiac involvement is extremely important in terms ofprognosis in the neonates with HIE. Cardiac evaluation and close followup should be performed for the better management of HIE. Cardiac biomarkers, ECG and ECHO are useful in the early recognition and evaluating the severity of myocardial damage in perinatal asphyxia.

Key Words: Cardiovascular instability, Myocardial damage, Perinatal asphyxia

\section{GiRiş}

Perinatal asfiksi yenidoğanda nörolojik, renal, kardiyak, hepatik ve hematolojik sistem dahil olmak üzere geçici ya da uzun süreli etkilere neden olabilir. En sık santral sinir sisteminin tutulumu olsa da, kardiyak fonksiyonlarla birlikte diğer birçok sistem de etkilenebilmektedir. Perinatal asfikside klinik olarak kardiyak disfonksiyon insidansı \%62-78 olarak bildirilmiştir. Bozulmuş miyokardiyal kontraktilite, düşük kalp hız ve hipotansiyon mortalitenin artmasına ve uzun dönem nörolojik sekellerin ortaya çıkmasına neden olabilmektedir. Hem hastalık süreci hem de tedavide etkinliği kanıtlanmış tek yöntem olan terapötik hipotermi hemodinamik dengesizliğe neden olabilir (1-5).

Bu çalışmanıntemel amacı terapötik hipotermi tedavisi uygulanan hipoksik iskemik ensefalopati (HIE) tanılı yenidoğanların kardiyak bulgularının incelenmesi, kardiyak etkilenme ve miyokardiyal zedelenme sürecinin saptanması için serum belirteçlerinden kreatinin kinaz-miyokard bandı (CK-MB) ve kardiyak troponin-I (cTnl ) ile elektrokardiyografi (EKG) ve konvansiyonel ekokardiyografi (EKO) parametrelerinin değerlendirmesidir. İkincil amaç ise Sarnat\&Sarnat evrelemesine göre Evre II ve Evre III HíE'lerin kardiyak bulgularının karşılaştırımasıdır.

\section{GEREÇ ve YÖNTEMLER}

Haziran 2019 - Şubat 2021 tarihleri arasında yenidoğan yoğun bakım ünitesinde yatırılarak izlenen Evre II ve EVRE III HIE tanısı ile terapötik hipotermi uygulanmış 50 yenidoğanın verileri retrospektif olarak analiz edildi. Çalışma için, Ankara Şehir Hastanesi etik kurul onayı alınarak gerçekleştirildi ( 07.04.2021E2-21-375). Hipoksik iskemik ensefalopati tanısı için Türk Neonatoloji Derneği'nin Neonatal Ensefalopati Tanı ve Tedavi Rehberi kullanıldı (6): Akut peripartum/intraparum olaya eşlik eden 1) Apgar skoru 5. ve 10. Dakikada <5 olması, 2) Fetal umbilikal kan gazında $\mathrm{pH}<7$ ve $\mathrm{BE}-12 \mathrm{mmol} / \mathrm{L}, \mathrm{MRI}$ veya MRS'da HIE ile uyumlu beyin hasarının görülmesi, 3) Çoklu organ yetmezliği veya etkilenmesinin olması tanı kriterleri olarak belirlendi. Evreleme modifiye Sarnat\&Sarnat kriterlerine göre yapıldı. Sarnat\&Sarnat'ın evrelendirmesine göre orta (Evre II) ve ağır (Evre III) (7) HíE olan ve hipotermi tedavisi uygulanan olgular çalışmaya alındı. Hipotermi tedavi kriterleri Türk Neonatoloji Derneğinin Neonatal Ensefalopati Tanı ve Tedavi Rehberinde önerilen 1) Gebelik yaşı $\geq 36$ ve $\leq 6$ saatten küçük bebekler 2) Kord kan gazında veya doğumdan sonraki ilk bir saat içerisinde bakılan $\mathrm{pH} \leq 7.00$ veya $\mathrm{BE} \leq-16 \mathrm{mmol} / \mathrm{L}$ olması 3) 10. dakika Apgar skoru $<5$ veya devam eden resusitasyon ihtiyacı 4) Klinik değerlendirmede orta veya ağır ensefalopati bulgularının olması olarak belirlendi (6).

Olguların birinci ve 5. dakika Apgar skorları, ilk 24 saat içindeki fizik muayene bulguları, EKG ve EKO bulguları ile birlikte doğum sonrası ikinci saatte bakılan serum CK-MB ve cTnl düzeyleri kaydedildi. CK-MB düzeyi İnterlab Microtech 648iso Electrophoresis 2002 (Roma İtaly) cihazında uygun elektroforez kitleri, cTnl düzeyi ise İmmulite (2000 Los Angeles USA Listed Laboratory Equipment) hormon otoanilazatörü ve İmmulite-2000 kitleri kullanılarak kemiluminesans yöntemi ile çalışıldı. Gebelik yaşı 35 haftadan küçük, major konjenital malformasyon, kromozom anomalisi, metabolik hastalık, ciddi hiperbilirubinemi, intrakraniyal kanama, menenjit, hipoglisemi, septik şok ve konjenital kalp hastalığı tanısı konulan bebekler araștırmaya dahil edilmedi.

\section{İstatistik Değerlendirme}

İstatistiksel analizi için SPSS 20.0 programı kullanıldı. Sürekli nicel veriler ortalama \pm standart sapma ve ortanca olarak, nitel veriler ise sayı (n) ve yüzdelik (\%) değerler olarak ifade edildi. Gruplar arası karşılaştırmada kategorik veriler için ki-kare testi ve normal dağılıma uymayan sayısal verilerde Mann-Whitney U testi kullanıldı. Veriler arasındaki ilişki Pearson korelasyon analizi ile değerlendirildi. $\mathrm{p}<0.05$ olması istatistiksel olarak anlamlı kabul edildi.

\section{BULGULAR}

\section{Hastaların Klinik Özellikleri}

Toplam 50 olgunun verileri analiz edildi. Sarnat\&Sarnat'ın evrelendirmesine göre olguların 24'ü (\%48) evre II, 26’sı (\%52) evre III HiE bulgularına sahipti. Doğum şekli 19'unda (\%38) 
Tablo I: Sarnat \&Sarnat'e göre Evre II ve Evre II'deki olguların demografik özellikleri.

\begin{tabular}{|c|c|c|c|}
\hline & Evre II $(n=24)$ & Evre III $(n=26)$ & $\mathbf{p}$ \\
\hline Doğum haftası & $38.28 \pm 2.17(38.5)$ & $38.33 \pm 1.61(39.1)$ & 0.55 \\
\hline Prematür/Matür (n\%) & $9 / 15(37.5 / 62.5)$ & $8 / 18(30.8 / 69.2)$ & 0.382 \\
\hline Doğum ağırlığı (gr) & $3110 \pm 501(3200)$ & $3225 \pm 363(3330)$ & 0.35 \\
\hline${ }^{*}$ Cinsiyet (K/E) & $13 / 11(54.2 / 45.8)$ & $10 / 16(38.5 / 61.5)$ & 0.270 \\
\hline *Doğum şekli (NSVY/CS) & $10 / 14(41.7 / 58.3)$ & 9/17 (34.6/65.4) & 0.611 \\
\hline${ }^{\dagger}$ Apgar skoru 1.dk & 5 (min-maks:3-6) ( 5) & 4 (min-maks:0-6) (4) & 0.019 \\
\hline${ }^{\dagger}$ Apgar skoru 5.dk & 7 (min-maks:5-8) (7) & 6 (min-maks:2-7) (6) & 0.004 \\
\hline Kord PH & $7.04 \pm 0.79(7.01)$ & $6.88 \pm 0.12(6.91)$ & 0.001 \\
\hline Kord BE (mmol/L) & $-16.23 \pm 2.17(-15.8)$ & $-21.46 \pm 5.74(-20.2)$ & 0.001 \\
\hline HCO3 (mEq/L) & $14.65 \pm 2.96(15.2)$ & $13.72 \pm 2.94(13.1)$ & 0.382 \\
\hline $\mathrm{PCO}_{2}(\mathrm{mmHg})$ & $56.96 \pm 17.63(59)$ & $67.11 \pm 22.56(72)$ & 0.027 \\
\hline Laktat (mmol/dL) & $6.95 \pm 2.84(6.12)$ & $9.54 \pm 3.71(9.9)$ & 0.016 \\
\hline KTA (atım/dk) & $113 \pm 15.3(108)$ & $104.65 \pm 12.85(103)$ & 0.629 \\
\hline SKB (mmHg) & $71.6 \pm 9.26(70.1)$ & $67.61 \pm 10.2(67.5)$ & 0.139 \\
\hline DKB (mmHg) & $45.58 \pm 5.81(45)$ & $48.84 \pm 7.1(44)$ & 0.585 \\
\hline Yatış süresi (gün) & $12.42 \pm 6.9(9.5)$ & $16.81 \pm 14.37(10)$ & 0.584 \\
\hline
\end{tabular}

Değerler Ort $\pm S D$ (ortanca) olarak verilmiştir, *Değerler sayı (n) ve (\%) olarak verilmiştir, ${ }^{\dagger}$ Değerler ortalama, (min-maks) (ortanca) olarak verilmiștir.

spontan vajinal yol (NSVY), 31'inde (\%62) sezaryen (C/S)'di. Perinatal olarak evre II HíE'de olguların 17'sinde (\%78.8) fetal distres, 5'inde (\%20.8) mekonyum aspirasyonu, 2'sinde (\%8) kordon dolanması ve prolapsusu; evre III HiE'de 12'sinde (\%46.2) fetal distres, 8'inde (\%30.8) mekonyum aspirasyonu, 4'ünde (\%15.4) kordon dolanması ve prolapsusu, 2'sinde (7.7) plasenta dekolmanı olduğu saptandı. Ortalama gebelik yaşı evre II ve III HIE için sırasılyla $38.3 \pm 2.2$ hafta, $38.3 \pm 1.6$ hafta, ortalama doğum ağırlığı sırasıly $3110 \pm 501 \mathrm{~g}$ ve $3225 \pm 363$ g idi. Evre II HiE'de 13 kIz ve 11 erkek, evre III HiE'de 10 kIz ve 16 erkek bebek vardı. Doğum haftası, doğum ağırlığı ve cinsiyet açısından gruplar arasında istatistiksel olarak anlamlı fark saptanmadı. Evre Il'de olgulardan 10'u (\%41.7), evre III'de 12'si (46.2) nöbet geçirmiști. Tüm olgulardan 48'i (\%98) taburcu edildi, sadece evre III HIE'de 1 hasta (\%2) exitus oldu. Yoğun bakımda yatış süresi evre Il'de $12.4 \pm 7$ gün, evre III'de ise $16.8 \pm 14$ gündü.

Evre II HiE'deki olguların 1. dakika Apgar skoru 5 (min-maks: 3-6), 5. dakika Apgar skoru 7 (min-maks: 5-8), evre III HiE'deki olguların 1. dakika Apgar skoru 4 (min-maks: 0-6), 5. dakika Apgar skoru 6 (min-maks: 2-7)'di (Tablo I). Kord kan gazı pH değeri evre II HiE'de 7.04 \pm 0.79 , evre III HIE'de 6.88 \pm 0.12 ; laktat düzeyleri evre II'de 6.95 \pm 2.84 , evre III'de $9.54 \pm 3.71$ olarak bulundu. Perinatal asfiksinin şiddeti arttıkça kord kan gazı $\mathrm{pH}$ değerinde azalma, laktat düzeyinde ise artış istatistiksel olarak anlamlı izlendi (Tablo I).

Evre II'de 1 olguya, evre III'de 2 olguya kardiyopulmoner resüsitasyon (KPR) yapılmıștı. Evre II'de 13 (\%54.2), evre III'de 17 (\%65.4) olguya pozitif basınçlı ventilasyon (PBV) yapılmıştı. Evre II'de 2 (\%8.3) olgu, evre III'de 4 (\%15.4) olgu entübeydi. Mekanik ventilasyon intiyacı $5.25 \pm 1.64$ gündü.
Klinik özelliklerine baktığımızda evre I'de 13'ü (\%54.2), evre III'de 12'si (\%46.2) asemptomatikti. Respiratuvar distres evre Il'de olguların 9'unda (\%37.5), evre III'de 9'unda (\%34.6) izlendi. Kalp yetersizliği evre II'de olguların 2'sinde (\%8.3), evre III'de 4'ünde (\%15.4), kardiyojenik şok tablosu evre III'de olguların 1'inde (\%3.8) vardı (Tablo II).

\section{Laboratuvar Bulguları}

İnterlökin-6 (IL-6) düzeyi evre Il'de 45.09 \pm 31.21 pg/ml, evre III'de $60.38 \pm 48.71$ 'di. IL-6 düzeyleri açısından gruplar arasındaki fark anlamlı iken, CRP düzeyleri açısından fark saptanmadı.

CK-MB düzeyi evre II'de 67.61 $\pm 41.55 \mathrm{U} / \mathrm{L}$, evre III'de 120.18 \pm 81.17 olarak bulundu. Evre II ve III HIE CK-MB düzeyleri arasında anlamlı fark vardı. Troponin-ı düzeyi evre Il'de $126.31 \pm 136.77 \mathrm{ng} / \mathrm{ml}$, evre III'de 742.13 $\pm 2352.1 \mathrm{ng} /$ ml'di (Tablo III). Hipoksik iskemik ensefalopati evresi ağırlaştıkça troponin-I düzeyinin istatistiksel olarak anlamlı yükseldiği gözlendi (Tablo III, $p<0.05$ ).

Troponin-I, IL-6 düzeyleri ile laktat düzeyleri arasındaki korelasyonun anlamlı olduğu saptandı (sırasıyla $r=0.350$, $p=0.013 ; \quad r=0.226, \quad p=0.332, \quad p=0.018)$. Ayrica troponin-I düzeyi ile entübasyon süresi arasındaki korelasyon anlamlı idi $(r=0.562, p=0.03)$. Troponin-I ve 1 ile 5. dakika Apgar skorları arasında negatif yönde anlamlı korelasyon vardı (sırasıyla $r=$ -0.410, $p=0.003 ; r=-0.466, p=0.001$ ). Inotrop destek intiyacl ile entübasyon süresi arasında pozitif yönde anlamlı korelasyon olduğu izlendi ( $r=0.656, p=0.021)$.

\section{EKG ve EKO Bulguları}

Tüm olgular normal sinüs ritmine sahipti ve 43'ünde (\%86) EKG bulguları normal olmakla birlikte, 7'sinde (\%14) miyokardiyal 
Tablo II: Sarnat \&Sarnat'e göre Evre II ve Evre IIl'deki olguların klinik özellikleri ve kardiyak bulguları.

\begin{tabular}{|c|c|c|c|}
\hline & Evre II (n\%) & Evre III (n\%) & $p$ \\
\hline $\begin{array}{l}\text { Klinik Özellikler } \\
\text { Asemptomatik } \\
\text { Respiratuvar distres } \\
\text { Kalp yetersizliği } \\
\text { Kardiyojenik şok }\end{array}$ & $\begin{array}{l}14(\% 58.3) \\
8(\% 33.3) \\
2(\% 8.3) \\
\quad-\end{array}$ & $\begin{array}{c}13(\% 50) \\
8(\% 30.8) \\
4(\% 15.4) \\
1(\% 3.8)\end{array}$ & 0.568 \\
\hline $\begin{array}{l}\text { EKG Bulguları } \\
\text { Normal } \\
\text { ST çökmesi } \\
\text { T dalga düzleşmesi-inversiyonu } \\
\text { Q dalgası }\end{array}$ & $\begin{array}{c}22(\% 91.7) \\
2(\% 8.3) \\
- \\
-\end{array}$ & $\begin{array}{l}21(\% 80.2) \\
3(11.5) \\
1(\% 3.8) \\
1(\% 3.8)\end{array}$ & 0.040 \\
\hline $\begin{array}{l}\text { Ekokardiyografi } \\
\text { Ventrikül fonksiyonu normal } \\
\text { RV hipokinezi } \\
\text { LV hipokinezi } \\
\text { Biventriküler hipokinezi }\end{array}$ & $\begin{array}{c}21(\% 87.5) \\
1(\% 4.2) \\
2(\% 8.3) \\
\quad-\end{array}$ & $\begin{array}{l}18(\% 69.2) \\
3(\% 11.5) \\
4(\% 15.4) \\
1(\% 3.8)\end{array}$ & 0.010 \\
\hline $\begin{array}{l}\text { Triküspit yetersizliği } \\
\text { Hafif } \\
\text { Orta } \\
\text { Ağır }\end{array}$ & $\begin{array}{c}4(\% 16.7) \\
1(\% 4.2) \\
-\end{array}$ & $\begin{array}{c}3(\% 11.5) \\
4(\% 15.4) \\
1(\% 3.8)\end{array}$ & 0.624 \\
\hline $\begin{array}{l}\text { Pulmoner hipertansiyon } \\
\text { Yok } \\
\text { Hafif } \\
\text { Orta } \\
\text { Ağır }\end{array}$ & $\begin{array}{c}19(\% 79.2) \\
4(\% 16.7) \\
1(\% 4.2)\end{array}$ & $\begin{array}{c}18(\% 69.2) \\
3(\% 11.5) \\
4(\% 15.4) \\
1(\% 3.8)\end{array}$ & 0.649 \\
\hline
\end{tabular}

Tablo III: Sarnat \&Sarnat'e göre Evre II ve Evre III'deki olguların kardiyak enzim ve diğer laboratuvar değerleri.

\begin{tabular}{|c|c|c|c|}
\hline & Evre II $(n=24)$ & Evre III $(n=26)$ & $p$ \\
\hline EF (\%) & $68.37 \pm 5.96(69.5)$ & $64.38 \pm 4.75(68)$ & 0.009 \\
\hline FS (\%) & $34.41 \pm 2.91(3.7)$ & $32.19 \pm 2.37$ (33) & 0.009 \\
\hline CK-MB (U/L) & $67.61 \pm 41.54(66.85)$ & $120.18 \pm 81.17(89.9)$ & 0.027 \\
\hline Troponin-I (pg/ml) & $126.31 \pm 136.77(95.1)$ & $742.13 \pm 2352.1$ (156.5) & 0.038 \\
\hline Üre (mg/dl) & $29.25 \pm 8.14(28)$ & $30.32 \pm 8.25$ (30) & 0.627 \\
\hline Kreatinin (mg/dl) & $0.72 \pm 0.18(0.73)$ & $0.71 \pm 0.27(0.7)$ & 0.655 \\
\hline AST (U/L) & $135.4 \pm 79.21(113)$ & $260.3 \pm 427.62(115)$ & 0.985 \\
\hline ALT (U/L) & $30.71 \pm 23.94(25)$ & $83.8 \pm 143.14$ (34.5) & 0.066 \\
\hline WBC $\left(\times 10^{3} / \mathrm{mm}^{3}\right)$ & $17.21 \pm 51.49(16.86)$ & $18.32 \pm 73.31(12.200)$ & 0.627 \\
\hline Hemoglobin (gr/dl) & $17.4 \pm 2.14(18.1)$ & $17.35 \pm 2.27(17.2)$ & 0.854 \\
\hline Hematokrit (\%) & $52.2 \pm 6.42(54.3)$ & $52.07 \pm 6.81(51.6)$ & 0.851 \\
\hline PLT $\left(x 10^{3} / \mathrm{mm}^{3}\right)$ & $278.623 \pm 78.83(253.5)$ & $261.653 \pm 58.54(266.1)$ & 0.614 \\
\hline CRP (mg/dl) & $2.54 \pm 1.86(3.11)$ & $3.22 \pm 2.39(3.11)$ & 0.783 \\
\hline IL-6 (ng/mL) & $45.09 \pm 31.21(34)$ & $60.38 \pm 48.71(44.5)$ & 0.201 \\
\hline
\end{tabular}

Değerler ort $\pm S D$ (ortanca) olarak verilmiştir.

iskemi bulguları vardı. Gruplara göre incelendiğinde Evre II'de 22 (\%91.7), evre III'de 21 bebeğin (\%80.2) EKG bulguları normaldi. Evre II'de 2 (\%8.3), evre III'de 3 (\%11.5) olguda ST segment çökmesi, evre IIl'de 1 olguda (\%3.8) T dalga düzleşmesiinversiyonu ve 1 olguda da (\% 3.8) miyokardiyal hasarı işaret eden anlamlı $Q$ dalgası mevcuttu. Iki grup arasındaki EKG bulguları açısından fark anlamlıydı (Tablo II). EKG bulguları ile serum troponin-। düzeyleri arasında anlamlı ilişki saptandı ( $p=0.591, p=0.001)$.
ÇalışmamızdaEKO'dakardiyak disfonksiyon bulgusu 50 olgunun 11 'inde (\%22) mevcutken, 39'unda (\%78) herhangi bir kardiyak fonksiyon bozukluğu saptanmadı. Ekokardiyografik M-mode ölçümlerden hesaplanan kardiyak kısalma fraksiyonu (KF) ve ejeksiyon fraksiyonu (EF) değerlerinin Evre III'deki olgularda Evre Il'ye göre daha düşük olduğu ve her iki grup arasında farkın anlamlı olduğu saptandı (Tablo III). Evre II'de 3 olguda (\%12.5), evre III'de 8 olguda (\%30.8) ventrikül disfonksiyonu izlendi. En yaygın değişiklik 11 olgunun 6'sında (\%12) bulunan 
sol ventrikül (LV) hipokinezisiydi. HIE evrelerine göre EKO'da kardiyak fonksiyonlar incelendiğinde; evre ll'de 2 olguda (\%8.3) LV hipokinezisi, 1 olguda (\%4.2) sağ ventrikül (RV) hipokinezisi, evre III'deki 4 olguda (\%15.4) LV hipokinezisi, 3 olguda (\%11.5) RV hipokinezisi ve 1 olguda (\%3.8) biventriküler hipokinezi görüldü. Sol ve sağ ventrikül hipokinezisi açısından gruplar arasındaki farkın anlamlı olduğu ve asfiksi evresi yükseldikçe kardiyak disfonksiyonun daha fazla olduğu saptandı (Tablo II).

Triküspit kapak yetersizliği evre Il'de olguların 4'ünde (\% 16.7) hafif, 1'inde (\%4.2) orta düzeyde, evre III'de ise 3'ünde (\% 11.5) hafif, 4'ünde (\%15.4) orta, 1 'inde (\%3.8) ağır düzeydeydi. Ekokardiyografide triküspit kapak yetersizliğinden hesaplanan pulmoner arter basıncına göre tüm olguların 7'sinde (\%14) hafif, 5 'inde (\%10) orta, 1'inde (\%2) ağır pulmoner hipertansiyon bulguları izlendi. Ensefelapatinin evrelerine göre pulmoner hipertansiyon; evre II'de olguların 4'ünde (\%16.7) hafif, 1'inde (\%4.2) orta, evre III'de ise 1'inde (\%3.8) ağır, 4'ünde (\%15.4) orta, 3'ünde (\%11.5) hafif düzeyde saptandı (Tablo II).

Ekokardiyografide ölçülen sol ventrikül KF ve EF değerleri ile serum troponin-I arasında anlamı ilişki saptandı (sırasıyla $r=$ $-0.432, p=0.002$ ve $r=-0.442, p=0.001$ )

Konjenital kalp anomalisi olarak tüm olguların 7'sinde (\%14) duktus arteriosus açıklı̆ı (DA), 10'nunda (\%20) atriyal septal defekt (ASD), 6'sinda (\%12) ventriküler septal defekt (VSD), 7 'sinde (\%14) mitral ya da triküspit kapak yetersizliği saptanırken, 20 'sinde (\%40) yapısal anomali saptanmadı.

\section{TARTIŞMA}

Hipoksik yenidoğanda klinik tabloya genellikle nörolojik değişiklikler hâkimdir. Ancak, multiorgan yetersizliği neonatal postasfiksiyal sendromun önemli bir özelliğidir. Perinatal asfiksili yenidoğanlarda kardiyak disfonksiyonu değerlendiren klinik çalışmalar sınırlı sayıdadır. Çalışmaların çoğunda kardiyak disfonksiyon oranı yaklaşık \%50-73 olarak bildirilmiştir $(8,9)$. Hindistan'da yapılan bir çalsşmada, ciddi perinatal asfiksisi olan yenidoğanların \%90'ında, orta derecede asfiksisi olan yenidoğanların \%40'ında miyokardiyal disfonksiyon bildirilmiștir (10).

Perinatal asfiksi yenidoğan döneminde mortalite ve morbiditenin en önemli nedenlerindendir. Sarnat evre III'teki bebeklerde mortalitenin yüksek olduğu bildirilmiștir $(3,8,9)$. Ülkemizden Ökten ve ark.'nın (11) çalışmasında evresine bakılmaksızın HiE'li bebeklerde mortalite \%18, Acunaş ve ark.'nın (12) çalışmasında ise asfiktik term bebeklerde mortalite oranı \%25 olarak bildirilmiştir. Türk Neonatoloji Derneği HİE çalsşma grubunun geniş serili çalıșmasında mortalite \%22.6 olarak bildirilmiștir (13). Çalıșmamızda Sarnat evre III'deki olgulardan sadece biri kaybedilmiştir. Araștırmalarda, kardiyak disfonksiyonun mortaliteye katkısı net olarak bildirilememiştir (14-16). Olguların \%62-78'inde diğer organlarda geri dönüşü olmayan hasara neden olabilecek kardiyak disfonksiyon olabileceği bildirilmiştir (3,17-19). Klinik bulgular, EKG değişiklikleri, konvansiyonel EKO bulguları, serum CK-MB ve cTnl düzeyine göre neonatal miyokardiyal hasar saptanmaya çalışlır (14,18-22).

Şu an ki bilgilerimize göre Türkiye'de HiE'li olgularda de kalp yetersizliği sıklığının belirlendiği bir çalışma henüz yayınlanmamışırı. Çalışmamızda tüm olgularımız içerisinde kalp yetersizliği kliniği \%12 oranında olup özellikle Sarnat klinik evre ağıllaştıkça kardiyak tutulumun arttığını saptadık. Sarnat evre III'deki 4 olguda kalp yetersizliği ve bir olguda kardiyojenik şok tablosu kliniği vardı. Mandal Ravi ve ark.'nın (23) perinatal asfiksili yenidoğanlarda yaptıkları çalışmalarında kalp yetersizliği oranı \%36 olarak bildirilmiştir. Herdy ve ark. (24) ise kalp yetersizliği oranını \%9 olarak bildirmişlerdir. Çalışmamızda Herdy ve ark'na göre HiE'li yenidoğanlarda kalp yetersizliği oranının daha yüksek olmasının, hem neonatoloji hem de perinatoloji bölümlerini içeren referans merkezi olmamıza bağlı olduğu düşünülmüştür.

Cochrane derlemelerinin sonuçlarına göre terapötik hipotermi yapılan olguların \%5'inde sinüs bradikardisi görülebildiği, ancak majör kardiyak aritmi, ağır hipotansiyon ve inotrop kullanılmasını gerektirecek hipotansiyonda artışa neden olmadığı bildirilmiştir (25). Bizim çalışmamızda da inotrop tedavi gerektirecek bradikardi ve hipotansiyonu saptanan olgumuz olmamıştır.

Miyokardın oksijen gereksinimi yüksek olduğundan, kardiyak etkiler sıklıkla perinatal asfikside görülebilmektedir. Bu olgularda kardiyak etkilenmenin erken tespiti tedavinin yönetimi için çok önemlidir (18). Ancak, yenidoğanlarda miyokardiyal disfonksiyonun değerlendirilmesi zordur. Çünkü klinik belirtilerin, kardiyak enzimlerin, EKG ve EKO bulgularının klinikde kullanımı farkllık gösterebilmektedir $(15,16)$. Ek olarak, neonatal miyokardiyal iskemi klinik olarak gizli olabilmektedir (14). Erişkinlerin aksine, yenidoğanda iskemik miyokardiyumu gösteren EKG değişiklikleri görülemeyebilir $(3,12)$. Miyokardiyal hasarı düşündüren EKO bulguları sadece miyokardiyal hasar şiddetli olduğunda izlenebilir $(3,4,15)$.

Pediyatrik popülasyonda troponinlerin, kalp cerrahisi ve kardiyotoksik ilaç tedavisini takiben miyokardiyal hasarın derecesi ile iyi bir korelasyon gösterdiği bildirilmiştir. Kardiyak biyobelirteçler solunum sıkıntısı ve asfikside miyokardiyal hasar şiddetinin değerlendirilmesinde yardımcı olabilir. Ayrıca, kardiyak biyobelirteçlerin EKO ile saptanan miyokardiyal fonksiyon bulguları ile iyi korelasyon gösterdikleri ve EKO olmayan merkezlerde fayda sağlayabileceği bildirilmiștir. Ancak troponinlerin yenidoğan yoğun bakım ünitesindeki kullanımı hala tartışmalıdır $(26,27)$.

EKG ve EKO kardiyak etkilenme ile ilgili sınırlı bilgi sağlamasına rağmen, hipokside kord kanı cTnl ve cTnT seviyeleri artmıştır. Kord kanındaki cTnl düzeyinin gestasyonel yaş ve doğum ağırlığından etkilenmediği bildirilmiştir (28-30). Çalışmamızda asfiksi evresi ile korele olarak cTnl düzeyinde belirgin yükseklik olduğu saptandı. Ayrıca Apgar skoru ve kord laktat düzeyi ile cTnl düzeyi arasında anlamlı bir ilişkinin olduğu görüldü. Bazı 
çalısmalarda cTnT'deki artışın prognostik bir belirteç olmasının yanı sıra, müdahale intiyacını da öngörebileceğini bildirilmiştir $(8,10,15)$. Biz de çalışmamızda inotrop tedavi intiyacının cTnl düzeyi yüksek olgularda daha fazla olduğunu saptadık. Bununla birlikte bradikardi, kapiller dolum süresi, kardiyak üfürüm, periferik soğukluk ve hipotansiyon gibi bazı klinik belirtilerin de, inotrop destek için gösterge olarak kabul edilerek uygulanacak tedavinin cTnT düzeylerine göre değil, klinik duruma göre belirlenmesi gerektiği vurgulanmıştır. Çünkü, troponin seviyeleri hipoksiye ikincil olmayan doğum sonrası kardiyorespiratuvar adaptasyonun varliğına bağlı olarak daha yüksek değerler gösterebilmektedir (29-31).

Perinatal asfikside uzun dönemde kalıcı sekellerin engellenmesi için erken tanı ve tedavi oldukça önemlidir. Ekokardiyografi bulunmayan hastanelerde alternatif olarak cTnl kullanımına dikkat edilmelidir. Çünkü konjenital kalp hastalığı, solunum sıkıntısı ve diğer klinik durumlar da cTnl düzeylerini yükseltebilir (26-29). Asfiksi sırasında koroner tutulum olmadığı ve koroner malformasyona bağlı iskemiden ayırım mutlaka yapılmalıdır. Wei ve ark. (19) serum cTnl düzeylerinin kontrol grubununa göre ağır asfiktik term yenidoğanlarda daha yüksek olduğu, hafif asfiktik olanlarda ise anlamlı fark olmadığı, asfiktik yenidoğanlarda kardiyak disfonksiyonu saptamadacTnl değerlerinin sensivitesinin az olduğunu bildirmişlerdir. Çalışmamız retrospektif olduğundan cTnl düzeyini karşılaștıracağımı kontrol grubumuz yoktu. Ancak evre III HiE'deki olgularımızda cTnl düzeyi daha yüksekti.

Szymankiewicz ve ark.(30) ortalama cTnT düzeyini asfiktik bebeklerde normal çocuklara göre anlamlı derecede daha yüksek bulmuş ve Apgar skoru hızla düzelen hastalarda cTnT düzeyini tedaviye iyi cevap vermeyen kliniği ağır gruba göre daha düşük saptamışlardır. Ayrıca inotropik destek intiyacı olanlarda ortalama cTnT düzeylerinin daha yüksek olduğunu ve en yüksek cTnT düzeylerinin ise exitus olan asfiktik bebeklerde saptandığını belirtmişlerdir. Bu çalışmada araştırmacılar kendi sonuçlarına dayanarak $>0.1 \mathrm{ng} / \mathrm{mlllik}$ cTnT düzeyinin, yenidoğanlarda hipoksiye sekonder kardiyak tutulum için referans bir değer olarak kabul edilebileceğini bildirmişlerdir (30).

Çalışmalarda perinatal asfiksili yenidoğanlarda cTnT düzeylerinin kontrol grubuna göre daha yüksek olduğu ve cTnT düzeylerinin HiE evresi ile ilişkili olduğu gösterilmiştir (18-27). Yıldırım ve ark. (31) çalışmasında perinatal asfiksili grupta CTnT ve CK-MB düzeyleri kontrol grubundakilere göre kardiyak hasar varliğını destekleyecek şekilde daha yüksekti. Bu çalsşmada cTnT için özgüllük ve duyarllığın birlikte en yüksek olduğu dönemlerin 12 . ve 24. saatte olduğu saptanmıștı. Troponin-T için özgüllük 24. saatte en yüksek değere ulașmıștı ve duyarlıık kordon kanında en yüksek değere sahipti (25). Biz olgularımızda sadece kord kanındaki troponin-I değerlerine baktığımızdan, izlemde troponin seyri için bir karşılaştırma yapamadık.

Çalıșmamızda evre III'de EKG bulgularının miyokardiyal iskemi ile değiştiği saptanmıştır. Barberi ve ark. (32) ciddi asfiksili hastalarda EKG'de değişiklikler gördüklerini bildirmişlerdir. Başka bir çalışmada asfiksili 30 yenidoğanın 4'ünde EKG'de değișiklikler saptanmıştır (29). Kanık ve ark.(3) ise EKG değişikliklerinin HiE evresi ile ilişkili olduğunu bildirmektedir (3). Diğer çalışmalarda olduğu gibi bizim çalıșmamı da perinatal asfiksili yenidoğanlarda EKG değişikliklerinin, azımsanmayacak sıklıkta görülebileceğine ișaret etmektedir. Bu nedenle asfiktik yenidoğanlarda EKG bulgularının kardiyak etkilenmeyi tanımlamak için değerlendirilmesinin uygun olacağı kanaatindeyiz.

Perinatal asfikside, özellikle orta ve șiddetli vakalarda ve ayırıcı tanıda ekokardiyografik değerlendirme gereklidir. EKO'da miyokardiyal hasarı temsil eden parametrelerden birincisi hem $\mathrm{KF}$, hem de peak aort hızının azalmasıyla ifade edilen deprese bir sol ventrikül fonksiyonudur. Ikinci olarak ise pulmoner hipertansiyon ile ilişkili triküspit yetersizliği değerlendirilir (18). Biz evre III'deki olgularımızda sol vetrikül KF değerlerini daha düşük saptadık.

Çalışmamızda EKO'da saptadığımız en sık değişiklik LV hipokinezisiydi. Şiddetli asfiksi olan bebeklerde kardiyak disfonksiyon ve dolayısıyla kalp yetmezliği olanların sayısı azımsanmayacak düzeydeydi. Tüm olgular içerisinde 7 olguda (\%14) hipotansiyonlu kalp yetmezliği veya inotrop destek gerektiren dolașım bozukluğu olduğunu saptadık. Çalıșmamızda LV hipokinezisi, 6 olguda (\%12), RV hipokinezisi 4 olguda (\%8), biventriküler hipokinezi 1 olguda (\%2) görüldü. Sonuçlarımız, vakalarının \%10'unda LV disfonksiyonu ve \%30'unda RV disfonksiyonu bildiren Perlman'ın gözlemleriyle tutarlıdır (33). Rajakumar ve ark. (10) çalışmasında 30 olgunun 6'sında (\%20 .0) RV hipokinezisi, 4'ünde (\%13.3) SV hipokinezisi saptanmıştır. Bu durumu sağ ventrikül kas kütlesinin daha fazla olması ve erken neonatal dönemde pulmoner basıncın yükselmesine bağlı yüksek after loadun, sağ ventrikülü miyokard iskemisine daha duyarlı hale getirdiği için sol ventrikül hipokinezisinden daha sık buldukları şeklinde açıklamışlardır.

Normal yenidoğan bebeklerde hafif triküspit yetersizliği nispeten yaygın olmasına rağmen, orta ve şiddetli triküspit yetersizliği, sıklıkla pulmoner hipertansiyon $(\mathrm{PH})$ ile ilişkilidir. Triküspit yetersizliği, papiller kas iskemisine veya kalıcı pulmoner hipertansiyona bağll olabilir. Triküspit yetersizliği Martein ve ark. nın (34) çalışmasında \%7, Flores ve ark. (35) tarafından ise \%21 olarak bildirilmiştir. Çalışmamızda tüm olguların 5'inde (\%10) orta derecede, 1'inde (\%2) ağır derecede triküspit yetersizliği görüldü. Sadece biventriküler disfonksiyon saptanan ve exitus olan bir olguda ağır PH vardı. Triküspit yetersizliğinin insidansındaki geniş çeşitlilik EKO'nun zamanlamasına bağlı olabilir.

Perinatal asfikside hipoksi çoklu organ lezyonlarından sorumludur. Yenidoğanda miyokard iskemisi genellikle perinatal asfiksi ile ilișkilidir. Perinatal asfikside çeșitli mekanizmalarla miyokardiyal perfüzyon korunmasına rağmen, ağır olgularda 
miyokardiyal hasar görülebilir. Geçici neonatal miyokard iskemisi matür yenidoğanda tanımlanmış olsa da prematürelerde de görülebilir. Bu çalsşmada LV KF değerleri evre III'deki olgularda daha düşük idi. Prospektif bir çalışmada depresif sol ventrikül fonksiyonu olan asfiktik yenidoğanların, yaygın miyokardiyal hasarve eşlik eden çoklu organ tutulumu nedeniyle prognozunun kötü olduğu bildirilmiştir (32).

Vaka sayısının görece olarak az olması, kritik yenidoğanların EKO laboratuvarına transferi riskli olduğundan yatak başında yapılan incelemeyle sadece sistolik foksiyonların değerlendirilmesi ve çalışmanın retrospektif olması araştırmanın temel kısıtlııklarıdır. Diyastolik fonksiyonları gösteren doku Doppler görüntüleme ve miyokardın aktif hareketini gösteren Strain EKO'nun yapılamaması çalışmanın diğer kısıtıııkları arasında kabul edilebilir.

Sonuç olarak perinatal asfiksiye sekonder miyokardiyal disfonksiyonun beklenenden yaygın olduğu, asfiktik yenidoğanlarda, hipoksinin şiddeti ile miyokardiyal tutulumun arasında bir ilişki olduğu görülmüştür. Asfiktik yenidoğanların kardiyak enzimler, EKG ve bozulmuş kardiyak fonksiyonu saptamak için EKO ile değerlendirilmesi önemlidir.

\section{KAYNAKLAR}

1. Nestaas E, Walsh BH. Hypothermia and Cardiovascular Instability. Clin Perinatol 2020;47:575-92.

2. Habib S, Saini J, Amendoeira S, McNair C. Hemodynamic Instability in Hypoxic Ischemic Encephalopathy: More Than Just Brain Injury-Understanding Physiology, Assessment, and Management. Neonatal Netw 2020; ;39:129-36.

3. Kanik E, Ozer EA, Bakiler AR, Aydinlioglu H, Dorak C, Dogrusoz $\mathrm{B}$, et al. Assessment of myocardial dysfunction in neonates with hypoxicischemic encephalopathy: is it a significant predictor of mortality? J Matern Fetal Neonatal Med 2009;22:239-42.

4. Popescu MR, Panaitescu AM, Pavel B, Zagrean L, Peltecu G, Zagrean AM. Getting an Early Start in Understanding Perinatal Asphyxia Impact on the Cardiovascular System. Front Pediatr 2020;8:68.

5. Sobeih AA, El-Baz MS, El-Shemy DM, Abu El-Hamed WA. Tissue Doppler imaging versus conventional echocardiography in assessment of cardiac diastolic function in full term neonates with perinatal asphyxia. J Matern Fetal Neonatal Med 2020;6:1-6.

6. Akisu M, Kumral A, Canpolat FE. Turkish Neonatal Society Guideline on neonatal encephalopathy. Turk Pediatri Ars 2018;53:S32-S44.

7. 7Sarnat HB. Neonatal encephalopathy following fetal distress. Arch Neurol 1976;33:696-705.

8. 8. Sadoh WE, Eregie CO, Nwaneri DU, Sadoh AE. The diagnostic value of both troponin $T$ and creatinine kinase isoenzyme (CK-MB) in detecting combined renal and myocardial injuries in asphyxiated infants. PLoS One 2014; 9:e91338.

9. Singh V, Vohra R, Bansal M. Cardiovascular involvement in birth asphyxia. J Clin Neonatol 2018;7:20-24.

10. Rajakumar PS, Vishnu Bhat B, Sridhar MG, Balachander J, Konar BC, Narayanan P, et al. Electrocardiographic and echocardiographic changes in perinatal asphyxia. Indian J Pediatr 2009;76:261-4.
11. Ökten A, Kamacı R, Mocan H. Hipoksik iskemik ensefalopatili 37 yenidoğanın bir yıllık izlemi ve nörolojik sekel oranları. Çocuk Sağlığı ve Hastalıkları Dergisi 1997;40:61-71.

12. Acunas B, Çeltik C, Garipardıç M, Karasalihoğlu S. Perinatal asfiksili yenidoğanların etyoloji, klinik ve prognoz açısından değerlendirilmesi. Türkiye Klinikleri J. Pediatr 1999; 8: 21-6.

13. Türk Neonatoloji Derneği Hipoksik İskemik Ensefalopati Çalışma Grubu. Türkiye'de yenidoğan yoğun bakım ünitelerinde izlenen hipoksik iskemik ensefalopatili olgular, risk faktörleri, insidans ve kısa dönem prognozları. Çocuk Sağlığı ve Hastalıkları Dergisi 2008;51:123-9.

14. Simovic AM, Prijic SM, Knezevic JB, Igrutinovic ZR, Vujic AJ, Kosutic JL. Predictive value of biochemical, echocardiographic and electrocardiographic markers in nonsurviving and surviving asphyxiated full-term newborns. Turk J Pediatr 2014;56:243-9.

15. Dattilo G, Tulino V, Tulino D, Lamari A, Falanga G, Marte F, et al. Perinatal asphyxia and cardiac abnormalities. Int $\mathrm{J}$ Cardiol 2011;147:e39-e40.

16. Merchant S, Meshram RM, Khairnar D. Myocardial ischemia in neonate with perinatal asphyxia: electrocardiographic, echocardiographic and enzymatic correlation. Indian J Child Health 2017;4:2-6.

17. Shah P, Riphagen S, Beyene J, Perlman M. Multiorgan dysfunction in infants with post-asphyxial hypoxicischaemic encephalopathy. Arch Dis Child Fetal Neonatal Ed 2004;89:152-5.

18. Papneja K, Chan AK, Mondal TK, Paes B. Myocardial infarction in neonates: a review of an entity with significant morbidity and mortality. Pediatr Cardiol 2017;38:427-41.

19. Wei Y, Xu J, Xu T, Fan J, Tao S. Left ventriküler systolic function of newborns with asphyxia evaluated by tissue dopler imaging. Pediatr Cardiol 2009;30:741-6.

20. Matter M, Abdel-Hady H, Attia G, Hafez M, Seliem W, Al-Arman M. Myocardial performance in asphyxiated full-term infants assessed by Doppler tissue imaging. Pediatr Cardiol 2010;31:634-42.

21. Teixeira RP, Neves AL, Guimarães H. Cardiac biomarkers in neonatology: BNP/NTproBNP, troponin $1 / T, \quad C K-M B$ and myoglobin-a systematic review. JPNIM 2017;6:e06021.

22. Bhasin H, Kohli C. Myocardial dysfunction as a predictor of the severity and mortality of hypoxic ischaemic encephalopathy in severe perinatal asphyxia: a case-control study. Paediatr Int Child Health 2019;39:259-64.

23. Mandal Ravi RN, Ruchi Gupta, Kapoor AK. Evaluation of activity of creatine Phosphokinase (CPK) and its Isoenzyme CPK-MB in perinatal asphyxia and its implications for myocardial involvement. Bull NNF 1999;13:2-7.

24. Herdy GV, Lopes VG, Aragão ML, Pinto CA, Tavares Júnior PA, Azeredo FB, et al. Perinatal asphyxia and heart problems. Arq Bras Cardiol 1998;71:121-6.

25. Jacobs SE, Berg M, Hunt R,Tarnow Mordi WO, Inder TE, Davis PG. Cooling for newborns with hypoxic ischaemic encephalopathy. Cochrane Database Syst Rev 2013;1: CD003311.

26. Gunes T, Ozturk MA, Koklu SM, Narin N, Koklu E. Troponin-T levels in perinatally asphyxiated infants during the first 15 days of life. Acta Paediatr 2005;94:1638-43.

27. Montaldo P, Cuccaro P, Caredda E, Pugliese U, De Vivo M, Orbinato $\mathrm{F}$, et al. Electrocardiographic and echocardiographic changes during therapeutic hypothermia in encephalopathic infants with long-term adverse outcome. Resuscitation 2018;130:99-104.

28. Turker G, Babaoglu K, Gokalp AS, Sarpen N, Zengin E, Arisoy AE. Cord Blood Cardiac Troponin I as an Early Predictor of Short-Term Outcome in Perinatal Hypoxia. Biol Neonate 2004; 86:131-7. 
29. Joseph S, Kumar S, Ahamed MZ, Lakshmi S. Cardiac troponin-T as a marker of myocardial dysfunction in term neonates with perinatal asphyxia. Indian J Pediatr 2018;85:877-84.

30. Szymankiewicz M, Matuszczak-Wleklak M, Hodgman JE, Gadzinowski $\mathrm{J}$. Usefulness of cardiac troponin $\mathrm{T}$ and echocardiography in the diagnosis of hypoxic myocardial injury of full-term neonates. Biol Neonate 2005;88:19-23.

31. Yildirim A, Ozgen F, Ucar B, Alatas O, Tekin N, Kilic Z. The Diagnostic Value of Troponin T Level in the Determination of Cardiac Damage in Perinatal Asphyxia Newborns. Fetal Pediatr Pathol 2016;35:2936.

32. Barberi I, Calabro MP, Cordaro S, Gitto E, Sottile A, Prudente D, et al. Myocardial ischaemia in neonates with perinatal asphyxia: electrographic, echocardiographic and enzymatic correlations. Eur J Pediatr 1999;158:742-7.

33. Perlman JM. Intrapartum hypoxic-ischemic cerebral injury and subsequent cerebral palsy: medicolegal issues. Pediatrics 1997;99:851-9.

34. Martin-Ancel A, Garcia-Alix A, GayaÁ F, Cabanas F, Burgu- eros M, Quero J. Multiple organ involvement in perinatal asphyxia. J Pediatr 1995; 127:786-93.

35. Flores-Nava G, Echevarría-Ybargüengoitia JL, Navarro- Barrón JL, García-Alonso A. Transient myocardial ischemia in newborn babies with perinatal asphyxia (hypoxic cardiomyopathy). Biol Med Hosp Infant Mex 1990;47:809-14. 